\title{
NEW POSSIBILITIES OF QUALITY REGULATION FOR CERAMIC PRODUCTS
}

\author{
Jurgita Malaiškienè ${ }^{1}$, Romualdas Mačiulaitis ${ }^{2}$ \\ Dept of Building Materials, Vilnius Gediminas Technical University, Saulettekio al. 11, LT-10223 Vilnius-40, \\ Lithuania.E-mail:1 orkute@one.lt; ${ }^{2}$ romualdas.maciulaitis@st.vtu.lt
}

Received 14 Jan 2004; accepted 25 Feb 2004

\begin{abstract}
Investigation of ceramic products is presented in the article. Material mix of these products consists of such components as clay of Rokai deposit, sand of Daugèliai deposit, crushed brick of Rokai brickworks, anthracite of Archangelsk region, peat of Rekyva's deposit and ground bottle glass. Statistical regression analysis is performed for the measured structural parameters of a ceramic body and various components of material mix. Empirical equations are derived allowing to select the composition of material mix according to the desirable structural parameters of a ceramic article (reserve of pore volume, degree of structural inhomogeneity, maximum rate of capillary wetting front, capillary rate of mass flow and total open porosity). After selecting the composition of material mix, the prognosis of ceramic body characteristics is performed. Results of the investigation will have a wide practical application.
\end{abstract}

Keywords: ceramics, structural parameters, components of material mix, quality regulation, regression analysis.

\section{Introduction}

Modern basis of technologies for producing building ceramics is programmable, computerised and controlled. However, the production of ceramic articles with particular characteristics and functions remains dependent on the peculiarities of clay used, additives, etc. Usually the best programme is applied. It determines the technological quality of the product with corresponding characteristics. Such production in principle allows ensuring the requirements of ISO 9001:2000 and ISO 9002:2000 standards and enables to regulate the quality of definite products. Optimal quality regulation systematic programmes become a commercial secret of enterprises. These programmes are usually prepared by scientists for mass production of specific building ceramic products taking into account the raw materials used, preparation of mixing, moulding, drying of products, conditions and regime of product burning.

Scientists have tried to perform a broader research and to obtain the generalised data on dependences and trends in material mix components, moulding and burning conditions of prefabs and mechanical, deformational and structural parameters of products, their chemical and mineralogical composition. There are not many scientific publications of this kind; their value is, however, very significant in practice.

The initiators working in this field of research in Lithuania were the authors of some publications [1-3]. They have proved a strong interdependence of frost resistance, compressive strength, bending strength of ceramic brick and the following technological factors: com- position and treatment of material mixture, level of vacuuming, drying and burning regimes, organic film used $[1,2]$. These scientists have also defined the interdependence of compressive and bending strength with rarefaction of material mix in vacuum chamber, length of pressing and formation heads [3]. They have proved these dependences by empirical formulas.

Much work in this field has been made by Professor A. Sadūnas [4]. He has analysed how the granulometric composition affects the rate of capillary wetting front, water absorption, bending strength, ultrasound speed, and frost resistance. The author has defined these dependences by regression equations and triangular diagrams, where optimal granulometric compositions for the particular characteristic of product are presented [4].

On the ground of our former investigations [5], the interdependence of service frost resistance and plasticity, dispersion of material mix, subproducts burning conditions and regime was found. Also the tendencies of structural parameters alteration dependent on the effective porosity and moulding method were established. However, these relations were not expressed by equations. Empirical equations describing the interdependence of the service frost resistance and structural, mechanical and other parameters are presented in publications [6-9].

These questions were analysed in detail by R. Žurauskienė [10] as well. By deriving empirical equations, she has proved that there are very heavy interdependences of total shrinkage, density, water absorption, compressive and bending strength, frost resistance and composition of material mix. 
In foreign countries many works on similar problems were performed by M. Dondi, et al [11]. They have graphically proved the ties between water vapour permeability and size of pores, open porosity and the ties between water vapour permeability and density, granulometric composition of clay. R. Glencross-Grant and P. Walker [12] in Australia have also graphically expressed the dependence between product strength and sand fineness.

Other foreign authors define the determined dependences by empirical equations [13, 14]. In the research work [13] the interdependences of compressive strength and composition of material mix are presented. Authors of publication [14] analyse the dependence of bending strength on the composition of a material mix.

The disadvantage of all the above-mentioned scientific investigations is such that only the interrelation is found between separate structural, mechanical and other physical parameters or the ties between them and some other technological factors. Thus in principle an attempt is made to highlight the general dependences and trends between one or another technological parameter, including the composition of material mix and other physicalmechanical or even chemical parameters. In some cases these are described quantitatively, indicating a definite dependence. This had a limited practical application.

Examples of analytical integrated solution of this problem have not been found in the literature.

Demand for this work is such: a plant could potentially produce different articles with available raw materials and equipment, for example, only by changing the composition of a material mix. Then the question is asked: what composition of material mix should be chosen in order to get the production of a desirable quality all other conditions being constant?

The aim of this work is to develop and present the new possibilities of production quality regulation system.

\section{Investigation methodology, raw materials}

Chemical composition of the main raw material (Rokai deposit clay) was determined by the classical methods of chemical analysis for silicate materials [15]. According to the chemical composition this clay is semiacid $\left(\mathrm{Al}_{2} \mathrm{O}_{3}-18,99 \%\right)$, with a large amount of ferrum oxide $(7,62 \%)$, the amount of effective clay oxides $\mathrm{Na}_{2} \mathrm{O}$ and $\mathrm{K}_{2} \mathrm{O}$ being $1,91 \%$. A large amount of $\mathrm{CaO}+\mathrm{MgO}$ $(11,23 \%)$ decreases in the interval of sintering.

Therefore the burning conditions get worse and the ceramic products become more porous [16]. Pure clay is rarely applied in production of bricks; usually technological disadvantages of clay are diminished by additives, according to the objectives being sought.

Granulometric composition of clay from Rokai deposit was determined according to GOST 21216.12. Average results are such: amount of clay particles is $84,1 \%$, dust particles $-15,3 \%$, sand particles $-0,6 \%$.

According to amount of clay particles, this clay is very dispersive. Plasticity of this clay (from 3-6 m depth) is 12.96 (according to GOST 21216.1) and by the plasticity value this clay is considered to be of limited plasticity.

Using the Rokai deposit clay as the main raw material, the samples were shaped in a plastic way. The clay used for material mixes was crushed to pieces of $1-3 \mathrm{~cm}$ size, dried, ground in rolls and passed through 0,63 $\mathrm{mm}$ aperture sieve.

Various additives are used for clay. They differ by their origin, purpose and properties. Search for necessary additives may take a lot of time, because the chosen additives improve only some of the product characteristics, while other features may get even worse. We have applied sand, crushed brick, anthracite, peat and ground glass as additives. Dosage of the components was performed by mass. Six different compositions of mixes were chosen (30 samples). This number of samples, representing the batch, ensures the reliability of results when $\mathrm{p}=0,05$. They are presented in Table 1 .

Before adding to the material mix, sand was passed through $0,63 \mathrm{~mm}$ sieve. Crushed brick was ground by alligator and passed through $1 \mathrm{~mm}$ sieve. These additives make the clay thin.

Peat was crushed manually and passed through 2 $\mathrm{mm}$ sieve. Anthracite of Archangelsk region was also passed through the same sieve. These additives are burnt out; they influence the parameter of total open porosity.

Glass was crushed in disintegrator and passed through $1 \mathrm{~mm}$ sieve. The additive to the crushed glass is effective when it makes approximately $20 \%$ in material mix. The increase of glass amount in a mix diminishes fireproofness of samples [17]. Also this additive should be dispersive enough, because during burning the coarser particles of ground glass may come to the surface of product.

Table 1. Composition of material mix

\begin{tabular}{c|c|c|c|c|c|c}
\hline $\begin{array}{c}\text { Number of } \\
\text { material mix }\end{array}$ & Clay $\left(y_{1}\right), \%$ & Sand $\left(y_{2}\right), \%$ & Crushed brick $\left(y_{3}\right), \%$ & Anthracite $\left(y_{4}\right), \%$ & Peat $\left(y_{5}\right), \%$ & Glass $\left(y_{6}\right), \%$ \\
\hline 1 & 74,5 & 18,0 & 6,0 & 1,5 & 0,0 & 0,0 \\
\hline 2 & 80,0 & 15,0 & 0,0 & 0,0 & 5,0 & 0,0 \\
\hline 3 & 70,5 & 12,0 & 6,0 & 1,5 & 0,0 & 10,0 \\
\hline 4 & 69,5 & 18,0 & 6,0 & 1,5 & 0,0 & 5,0 \\
\hline 5 & 59,5 & 18,0 & 6,0 & 1,5 & 0,0 & 15,0 \\
\hline 6 & 54,0 & 30,0 & 5,0 & 1,0 & 0,0 & 10,0 \\
\hline
\end{tabular}


Table 2. Specific characteristics of structural parameters [5]

\begin{tabular}{|c|c|c|c|}
\hline Notation & $\begin{array}{c}\text { Description of the basic } \\
\text { parameter and units of } \\
\text { measurement }\end{array}$ & $\begin{array}{l}\text { Formulas for } \\
\text { determination }\end{array}$ & $\begin{array}{c}\text { Description of the partial values and units of } \\
\text { measurement }\end{array}$ \\
\hline$x_{1}$ & Reserve of pore volume $R_{p}, \%$ & $R_{p}=\left(1-\frac{W_{e}}{W_{p}}\right) \cdot 100$ & $\begin{array}{l}W_{e}-\text { effective porosity according to the water } \\
\text { absorption after } 72 \mathrm{~h}, \% \\
W_{p}-\text { total open porosity according to the water } \\
\text { absorption in the vacuum process, } \%\end{array}$ \\
\hline$x_{2}$ & $\begin{array}{c}\text { Degree of structural } \\
\text { inhomogeneity } N_{H} \text {, units }\end{array}$ & $N_{H}=\frac{H_{\max }-H_{\min }}{H_{\min }}$ & $H_{\max }, H_{\min }-$ value after $2 \mathrm{~h}$ experiment \\
\hline$x_{3}$ & $\begin{array}{l}\text { Maximum rate of capillary } \\
\text { wetting front } H_{\max }, \mathrm{mm} / \mathrm{h}\end{array}$ & - & $H_{\max }-$ after $1 \mathrm{~h}$ experiment \\
\hline$x_{4}$ & $\begin{array}{l}\text { Capillary rate of mass flow } G, \\
\qquad \mathrm{~g} / \mathrm{cm}^{2} \cdot \mathrm{h}\end{array}$ & $G=\frac{m_{1}-m}{S}$ & $\begin{array}{l}m_{1}-\text { mass of a sample saturated by the capillary } \\
\text { suction process, } \mathrm{g}, \text { after } 1 \mathrm{~h} \\
m \text { - mass of sample dried up to the constant weight, } \mathrm{g} \\
S \text { - surface area of sample, } \mathrm{cm}^{2}\end{array}$ \\
\hline$x_{5}$ & Total open porosity $W_{p}, \%$ & $W_{p}=\frac{m_{2}-m}{V} \cdot 100$ & $\begin{array}{l}m_{2}-\text { mass of sample saturated by the vacuum process } \\
\text { in air, } \mathrm{g} \\
m \text { - mass of sample dried up to the constant weight, } \mathrm{g} \\
V-\text { volume of sample with open pores, } \mathrm{cm}^{3} \\
\text { For calculations it is assumed that for water } 1 \mathrm{~g}=1 \mathrm{~cm}^{3}\end{array}$ \\
\hline
\end{tabular}

At first dry materials were mixed manually, later the mix was wetted to the moisture suitable for moulding. The amount of water poured was such that the material mix would be easily moulded. Such mix was left for three days in the $(95 \pm 5) \%$ relative humidity medium for moisture evenly spreading in the mix.

After three days the laboratory samples were shaped into the dimensions $70 \times 70 \times 70 \mathrm{~mm}$. These prefabs were dried at first under natural conditions, later they were left to dry for one day in the electric stove with temperature $(105 \pm 5){ }^{\circ} \mathrm{C}$. The dried samples were burned in an experimental chamber oven for 24 hours. The maximum $1080{ }^{\circ} \mathrm{C}$ temperature was maintained for 3 hours. The burning regime was not varied during our investigation.

The burned samples were used to determine and calculate principal and derivative structural parameters: 1) reserve of pore volume $\left.\left(x_{1}=R_{p}\right), 2\right)$ degree of structural inhomogeneity $\left.\left(x_{2}=N_{H}\right), 3\right)$ maximum rate of capillary wetting front $\left(x_{3}=H_{\max }\right)$, 4) capillary rate of mass flow $\left(x_{4}=G\right)$, and 5) total open porosity $\left(x_{5}=W_{p}\right)$.

The physical sense of these parameters may be described in the following way.

Reserve of pore volume characterises the amount of reserve pores and capillaries, where water hardly penetrates. The larger the reserve of pore volume, the bigger usually is the frost resistance of a ceramic body. Degree of structural inhomogeneity allows evaluating the unevenness of effective capillary structure according to their reciprocal length. Maximum rate of capillary wetting front indicates the relative length of effective capillaries. Capillary rate of mass flow defines the equivalent diameter of these capillaries. Parameter of total open porosity characterises the total open porosity space of ceramic sample in the aspect of macrostructure and microstructure.

The technique for calculation of parameters is presented in Table 2. The calculated characteristic values of these parameters can be found in Table 3 .

Table 3. The main parameters of ceramic samples and their characteristic values

\begin{tabular}{c|c|c|c|c|c}
\hline $\begin{array}{c}\text { Number of } \\
\text { material mix }\end{array}$ & $\begin{array}{c}R_{p} \\
\left(x_{1}\right) \\
\%\end{array}$ & $\begin{array}{c}N_{H} \\
\left(x_{2}\right) \\
\text { units }\end{array}$ & $\begin{array}{c}H_{\max } \\
\left(x_{3}\right) \\
\mathrm{mm} / \mathrm{h}\end{array}$ & $\begin{array}{c}G \\
\left(x_{4}\right) \\
\mathrm{g} / \mathrm{cm}^{2} \cdot \mathrm{h}\end{array}$ & $\begin{array}{c}W_{p} \\
\left(x_{5}\right) \\
\%\end{array}$ \\
\hline 1 & 42,43 & 2,09 & 29 & 0,33 & 29,35 \\
\hline 1 & 45,06 & 2,02 & 35 & 0,32 & 28,13 \\
\hline 2 & 36,17 & 2,01 & 36 & 0,80 & 33,20 \\
\hline 2 & 38,54 & 1,66 & 37 & 0,53 & 32,78 \\
\hline 3 & 66,29 & 4,09 & 20 & 0,09 & 17,02 \\
\hline 3 & 64,26 & 3,98 & 18 & 0,11 & 15,37 \\
\hline 4 & 47,56 & 2,65 & 22 & 0,13 & 19,16 \\
\hline 4 & 50,54 & 3,05 & 23 & 0,22 & 19,19 \\
\hline 5 & 70,21 & 5,44 & 11 & 0,03 & 11,35 \\
\hline 5 & 72,76 & 5,76 & 13 & 0,01 & 9,20 \\
\hline 6 & 49,08 & 4,66 & 22 & 0,22 & 18,34 \\
\hline 6 & 51,12 & 4,35 & 21 & 0,12 & 17,55 \\
\hline
\end{tabular}

\section{Statistical analysis of data}

At first statistical analysis of all structural parameters was performed: the maximum and minimum values were determined, the average and dispersion were calculated, tables of frequencies were constructed, and histograms drawn. This analysis demonstrated that parameters 
vary in a quite wide interval; they change according to the normal distribution and represent the analysed set well enough.

Then the first stage of regression analysis was performed and empirical equations (1)-(6) obtained. Adequacy of equations was verified applying the Fisher's criteria.

Significance of equation variables (according to the Student criteria: if the value is bigger than the one found in tables, the regression coefficient is significant) [1820 ], the multiple correlation coefficient (numerical characteristics, evaluating linear relationship) [21], the determination coefficient (numerical characteristics, evaluating suitability of model) and the standard deviation are presented in Table 4.

$$
\begin{aligned}
& y_{1}=35,5+0,97 x_{1}-8,72 x_{2}-0,40 x_{3}+18,7 x_{4}+0,80 x_{5} \\
& y_{2}=54,5-1,04 x_{1}+6,76 x_{2}+0,36 x_{3}-16,8 x_{4}-0,44 x_{5} \\
& y_{3}=17,8-0,07 x_{1}+0,74 x_{2}-0,07 x_{3}-7,10 x_{4}-0,18 x_{5} \\
& y_{4}=4,07-0,001 x_{1}-0,31 x_{2}-0,02 x_{3}-1,47 x_{4}-0,04 x_{5} \\
& y_{5}=-11,5+0,11 x_{1}+0,20 x_{2}+0,04 x_{3}+6,92 x_{4}+0,16 x_{5} \\
& y_{6}=-0,76+0,03 x_{1}+2,81 x_{2}+0,10 x_{3}-0,24 x_{4}-0,30 x_{5}
\end{aligned}
$$

Multiple correlation coefficient $\mathrm{R}$ and determination coefficient $\mathrm{R}^{2}$ in $\mathrm{Eq}$ (1) are close enough to the unit (Table 4), therefore it may be concluded that the model chosen is correct and there is a strong mutual dependence of parameters. According to the values of Student criteria, all structural parameters for clay quantity are significant. Most of all clay quantity interacts with parameters of reserve of pore volume and degree of structural inhomogeneity. The bigger the reserve of pore volume and the smaller the degree of structural inhomogeneity, the larger amount of clay should be added to the material mix.

Multiple correlation coefficient in Eq (2) is also very close to the unit and the standard deviation is $\mathrm{s}_{\mathrm{e}}=1,46 \%$ (Table 4). Therefore the dependence of the amount of sand and the structural parameters chosen is very good. The amount of sand (the same as of clay) is mostly in- fluenced by the reserve of pore volume and by the degree of structural inhomogeneity. Only the impact of these parameters is different: the bigger the reserve of pore volume and the smaller the degree of structural inhomogeneity, the smaller amount of sand should be in the material mix. The amount of sand is important for other parameters as well, because their Student criterion values are bigger than the value $(2,04)$ in the Table.

Determination coefficient in Eq (3) $R^{2}=0,607$ is smaller (Table 4). However, the chosen model is still considered suitable [18], because $\mathrm{R}^{2}>0,5$, and standard deviation $\mathrm{s}_{\mathrm{e}}=1,54$. Structural parameters for amount of crushed brick are not very significant, because their Student criterion value is smaller than the one $(2,04)$ in the Table.

Determination coefficient in Eq (4) (Table 4) is a little bit bigger than in Eq (3) and the model is also considered to be suitable [18]. Moreover, the standard deviation is small enough $(0,39)$. The amount of anthracite only slightly interacts with the degree of structural inhomogeneity, because Student criterion value is only a little bit bigger $(2,04)$ than the one in the Table.

Determination coefficient in Eq (5) is slightly bigger than the Eq (4), and the dependence is considered to be suitable again. Standard deviation is 1,29. The amount of peat interacts with structural parameters more than those of anthracite or crushed brick. Most of all the amount of peat interacts with the parameter of capillary rate of mass flow. The rate increases, increasing the amount of peat in the material mix.

By Eqs (3), (4) and (5) it may be concluded that crushed brick, anthracite and peat in small amounts do not produce a considerable impact on structural parameters. This phenomenon may be explained by the fact that coefficients of pair correlation of the structural parameters are quite large and in some cases significant. It would be desirable that the parameters would not correlate with each other, however, the reality shows that the structure of ceramic body as the object of investigation is characterised by various structural parameters.

Table 4. Statistical parameters of empirical equations (1)-(6)

\begin{tabular}{c|c|c|c|c|c|c|c|c}
\hline \multirow{2}{*}{$\begin{array}{c}\text { Number of } \\
\text { equation }\end{array}$} & $\mathrm{R}$ & \multirow{2}{*}{$\mathrm{R}^{2}$} & \multirow{2}{*}{$\begin{array}{c}\mathrm{s}_{\mathrm{e}}, \\
\mathrm{\%}\end{array}$} & & \multicolumn{5}{|c}{ Calculated values of Student criteria } \\
\cline { 5 - 9 } & & & & $\begin{array}{c}\text { Reserve of } \\
\text { pore } \\
\text { volume, } \\
\left(x_{1}\right)\end{array}$ & $\begin{array}{c}\text { Degree of } \\
\text { structural } \\
\text { inhomogeneity, } \\
\left(x_{2}\right)\end{array}$ & $\begin{array}{c}\text { Maximum rate } \\
\text { of capillary } \\
\text { wetting front } \\
\left(x_{3}\right)\end{array}$ & $\begin{array}{c}\text { Capillary } \\
\text { rate of } \\
\text { mass flow, } \\
\left(x_{4}\right)\end{array}$ & $\begin{array}{c}\text { Total open } \\
\text { porosity, }\end{array}$ \\
\hline 1 & 0,984 & 0,969 & 1,74 & 13,94 & 13,18 & 3,33 & 4,18 & 3,82 \\
\hline 2 & 0,972 & 0,945 & 1,46 & 17,75 & 12,14 & 3,60 & 4,47 & 2,52 \\
\hline 3 & 0,779 & 0,607 & 1,54 & 1,08 & 1,26 & 0,67 & 1,80 & 0,98 \\
\hline 4 & 0,781 & 0,610 & 0,39 & 0,08 & 2,10 & 0,93 & 1,49 & 0,89 \\
\hline 5 & 0,787 & 0,619 & 1,29 & 2,06 & 0,41 & 0,40 & 2,10 & 1,05 \\
\hline 6 & 0,990 & 0,981 & 0,86 & 0,89 & 8,60 & 1,65 & 0,11 & 2,87 \\
\hline
\end{tabular}


Table 5. Empirical equations, their correlation and reliability

\begin{tabular}{c|l|c|c|c}
\hline No & \multicolumn{1}{|c|}{ Parameter } & Empirical equations derived & $\mathrm{R}$ & Variac Expl, \% \\
\hline 7 & Reserve of pore volume $\left(x_{1}\right)$ & $x_{1}=0,47 y_{1}-0,33 y_{2}+1,85 y_{3}+1,06 y_{4}+1,32 y_{5}+2,36 y_{6}$ & 0,988 & 97,66 \\
\hline 8 & $\begin{array}{l}\text { Degree of structural } \\
\text { inhomogeneity }\left(x_{2}\right)\end{array}$ & $x_{2}=0,01 y_{1}+0,03 y_{2}+0,11 y_{3}-0,08 y_{4}+0,09 y_{5}+0,24 y_{6}$ & 0,984 & 96,74 \\
\hline 9 & $\begin{array}{l}\text { Maximum rate of capillary } \\
\text { wetting front }\left(x_{3}\right)\end{array}$ & $x_{3}=0,57 y_{1}+0,54 y_{2}-3,01 y_{3}-2,83 y_{4}-3,42 y_{5}-0,59 y_{6}$ & 0,931 & 86,72 \\
\hline 10 & Capillary rate of mass flow $\left(x_{4}\right)$ & $x_{4}=-0,001 y_{1}+0,008 y_{2}+0,06 y_{3}-0,10 y_{4}+0,09 y_{5}-0,02 y_{6}$ & 0,916 & 83,85 \\
\hline 11 & Total open porosity $\left(x_{5}\right)$ & $x_{1}=0,47 y_{1}-0,33 y_{2}+1,85 y_{3}+1,06 y_{4}+1,32 y_{5}+2,36 y_{6}$ & 0,982 & 96,40 \\
\hline
\end{tabular}

Eq (6) shows that crushed glass is a very important component of material mix according to the structural parameters. It decreases the total porosity, it increases both the reserve of pore volume and the degree of structural inhomogeneity. It also decreases the capillary rate of mass flow.

Hence Eqs (1)-(6) demonstrate that the most important components of ceramic body material mix are clay and glass. In this case sand, crushed brick, anthracite and peat have less influence.

After that the second stage of regression analysis was performed (functions correspond to letter $\mathrm{x}$, arguments to letter y). The obtained empirical equations of contrary dependence are presented in Table 5.

Eq (7) states (Table 5) that clay, peat and glass increase the reserve of pore volume. Mostly the reserve is increased by ground glass. The degree of structural inhomogeneity (equation 8) is mostly increased by glass and sand. According to empirical Eq (9) (Table 5), the value of maximum rate of capillary wetting front mostly depends on the amount of glass and sand and less on the amounts of crushed brick and anthracite.

Crushed brick and anthracite decrease the parameter of maximum capillary wetting front, and sand does increase.

Clay and peat have only little influence on parameter of maximum capillary wetting front. According to the empirical Eq (10) (Table 5), capillary rate of mass flow mostly depends on the amount of glass and peat and it depends less on anthracite.

According to Eq (11) (Table 5), the total open porosity is mostly affected by glass and clay. Glass decreases the value of total open porosity, because it melts quickly and fills the pores of sample. Clay increases the total porosity and this may be explained by the fact that the Rokai deposit clay contains a lot of burning out additives $(9,79 \%)$.

From the data (Table 5) such generalisation may be made again: the main components of material mix having influence on the structural parameters are clay and glass.

This is also proved by the data in Table 6 , where pair correlation between clay, glass and structural parameters is very strong and important. In publication [22] one can find that sintered ceramics may be produced only from clay and glass, where the amount of glass is 10$20 \%$. This is also approved by our investigation.

Comparison of theoretical (calculated by empirical equations) and experimental values of clay and glass are presented in Figs 1 and 2.

\section{Examples of equations application}

Choosing the desirable features of a ceramic product, it is necessary to take into account the matrix pair correlation coefficients (Table 6), because tendencies of relation between corresponding structural parameters and components of material mix are presented in the matrix. Values of the selected parameters must not contradict the laws of dependences.

1 example. Let's say ceramic products with such structural parameters should be produced: reserve of pore volume $65 \%$, degree of structural inhomogeneity $4 \%$, maximum rate of capillary wetting front $18 \mathrm{~mm} / \mathrm{h}$, capillary rate of mass flow $0,1 \mathrm{~g} / \mathrm{cm}^{2} \cdot \mathrm{h}$, total open porosity $16 \%$. In this case the values should be written to

Table 6. Matrix pair correlation coefficients $\mathrm{R}$

\begin{tabular}{|c|c|c|c|c|c|}
\hline $\begin{array}{l}\text { Parameters } \\
\text { Components of } \\
\text { material mix }\end{array}$ & $\begin{array}{l}\text { Reserve of pore } \\
\text { volume, } \\
\left(x_{1}\right)\end{array}$ & $\begin{array}{c}\text { Degree of } \\
\text { structural } \\
\text { inhomogeneity } \\
\qquad\left(x_{2}\right)\end{array}$ & $\begin{array}{c}\text { Maximum rate of } \\
\text { capillary wetting } \\
\text { front } \\
\left(x_{3}\right)\end{array}$ & $\begin{array}{l}\text { Capillary rate of } \\
\text { mass flow } \\
\left(x_{4}\right)\end{array}$ & $\begin{array}{c}\text { Total open } \\
\text { porosity } \\
\left(x_{5}\right)\end{array}$ \\
\hline Clay $\left(y_{1}\right)$ & $-0,50 *$ & $-0,83 *$ & $0,64 *$ & $0,62 *$ & $0,74^{*}$ \\
\hline Sand $\left(y_{2}\right)$ & $-0,20$ & 0,28 & $-0,04$ & $-0,04$ & $-0,13$ \\
\hline Crushed bricks $\left(y_{3}\right)$ & $0,56 *$ & $0,51 *$ & $-0,68 *$ & $-0,73 *$ & $-0,68 *$ \\
\hline Anthracite $\left(y_{4}\right)$ & $0,58 *$ & $0,45 *$ & $-0,67 *$ & $-0,71 *$ & $-0,65^{*}$ \\
\hline Peat $\left(y_{5}\right)$ & $-0,53 *$ & $-0,55 *$ & $0,67 *$ & $0,72 *$ & $0,69 *$ \\
\hline Glass $\left(y_{6}\right)$ & $0,89 *$ & $0,98 *$ & $-0,87^{*}$ & $-0,83^{*}$ & $-0,95^{*}$ \\
\hline
\end{tabular}

Remark: * - pair correlation coefficient is significant 


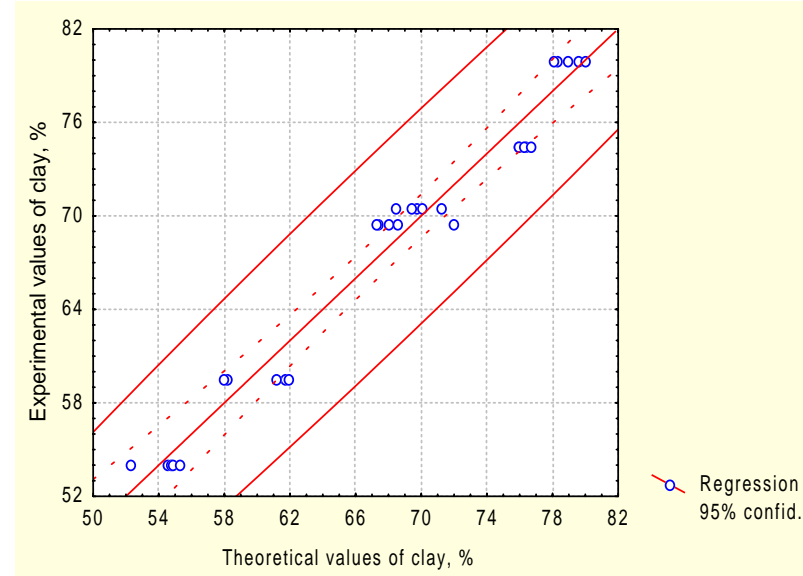

Fig 1. Comparison of theoretical and experimental values of clay amount calculated according to the structural parameters

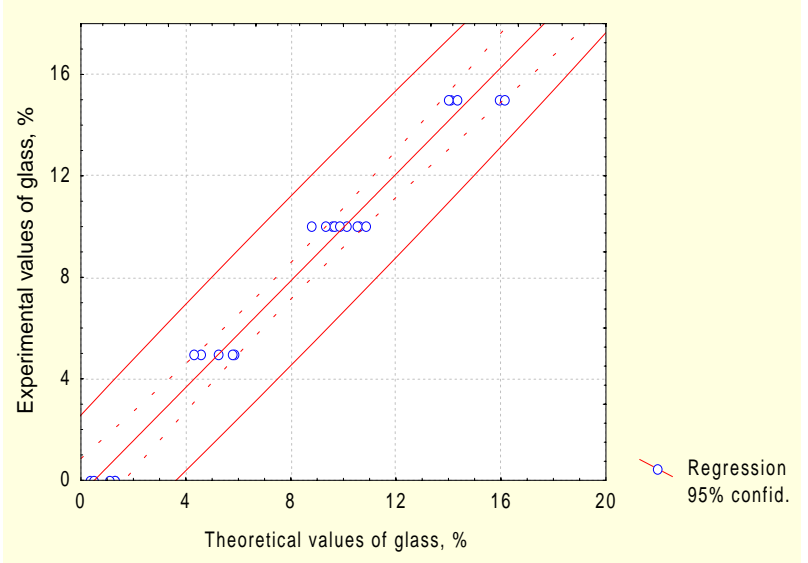

Fig 2. Comparison of theoretical and experimental values of glass amount calculated according to the structural parameters

Eqs (1)-(6) and the following composition of material mix is obtained: clay $-71 \%$, sand $-12 \%$, crushed brick $-6 \%$, anthracite $-2 \%$, peat $-0 \%$, glass $-9 \%$. Then these values are written to Eqs (7)-(11) and the parameters are calculated: the expected reserve of pore volume - 63,9\%, degree of structural inhomogeneity $3,7 \%$, maximum rate of capillary wetting front $17,9 \mathrm{~mm} / \mathrm{h}$, capillary rate of mass flow $-0,01 \mathrm{~g} / \mathrm{cm}^{2} \cdot \mathrm{h}$, total open porosity $-15,4 \%$. So the calculated values differ very slightly from those given in the task. In this case the structural parameters of products will be similar to those of sintered ceramics.

2 example. Let's say that more porous ceramic products should be produced, the ones similar to effective ceramics by structural characteristics. Then the following structural parameters may be selected: reserve of pore volume $40 \%$, degree of structural inhomogeneity $2 \%$, maximum rate of capillary wetting front $32 \mathrm{~mm} / \mathrm{h}$, capillary rate of mass flow $0,4 \mathrm{~g} / \mathrm{cm}^{2} \cdot \mathrm{h}$, total open porosity $30 \%$. Then the values should be written to Eqs (1)-(6) and the following composition of material mix is ob- tained: clay $-76 \%$, sand $-18 \%$, crushed bricks $-3 \%$, anthracite $-1 \%$, peat $-2 \%$, glass $-0 \%$. These values are written to Eqs (7)-(11) and the supposed parameters of building ceramics are calculated: the expected reserve of pore volume - 39,0 \%, degree of structural inhomogeneity $-1,7 \%$, maximum rate of capillary wetting front $-34,3 \mathrm{~mm} / \mathrm{h}$, capillary rate of mass flow $-0,33 \mathrm{~g} / \mathrm{cm}^{2} \cdot \mathrm{h}$, total open porosity $-30,0 \%$. The calculated values differ also very slightly from those in the task and even the total porosity is the same.

The examples show that for producing porous ceramics peat should be added to the material mix and the amount of ground glass should be diminished to the minimum or even not added at all. When producing the sintered ceramics, the addition of ground glass is the most effective; it is recommended to decrease slightly the amount of clay and sand, to increase the amounts of crushed brick, anthracite; peat should not be used. The examples given in the article also show that it is possible to regulate effectively in this way the quality of production.

\section{Conclusions}

1. The interdependence of composition of material mix and structural parameters is great. Multiple correlation coefficients describing the dependence vary from 0,779 to 0,990 . It has been proved that structural parameters are mostly affected by amounts of clay and glass; their multiple correlation coefficients are 0,984 and 0,990 respectively. Amounts of crushed brick, anthracite and peat have a slighter interaction with structural parameters $(\mathrm{R}=0,779 \ldots 0,787)$. The mutual dependence of separate structural parameters and components of material mix is also great $(\mathrm{R}=0,916 \ldots 0,988)$.

2. After checking the conformity of experimental results to the values obtained by empirical equations, it has been found that composition of material mix may be selected according to the desirable properties of product and vice versa, after selection of material mix composition, the final properties of product may be foreseen.

It has been proved in this way that when producing ceramic products, a new and efficient quality regulation system may be applied.

3. The examples show that producing sintered ceramics quite large amounts of ground glass are to be added $(>15 \%)$ but peat should not be used. Peat additive $(>5 \%)$ suits when porous ceramics is produced, but ground glass should not be applied in this case.

\section{Literature}

1. Petrikaitis, F.; Jarulaitis, V.; Kaminskas, E.; Daujotas, V. Influence of technological factors to quality of façade bricks (Влияние технологических факторов производства на качество лицевого кирпича). Building materials (Строительные материалы), № 4, 1974, p. 10-13 (in Russian). 
2. Jarulaitis, V.; Petrikaitis, F.; Daunoravičiute, D.; Kaminskas, E. Mathematical valuation of technological factors influence on quality of building ceramics (Mathematische Beurteilung der Einflusse technologischen Herstellungsfaktores auf die Qualität von Baukeramik). Journal of Ceramics (Keramische Zeitschrift), Jahrgang, No 10, 1988, p. 761-762 (in German).

3. Jarulaitis, V.; Petrikaitis, F.; Daunoravičiute, D.; Kaminskas, E. Mathematical valuation of technological factors influence on quality of building ceramics (Математическая оценка влияния технологических факторов производства на качество строительной керамики) 10. Ibausil. 10. In: International Building Materials and Silicates. Proceedings of conference (Internationale Baustoff und Silikattagung. Tagungsbericht), Part 3. Weimar, 1988, p. 311-313 (in Russian).

4. Sadūnas, A. Durability of aluminium silicate products (Aliumosilikatinių dirbinių ilgaamžiškumas). Vilnius: VPU, 1997. 252 p. (in Lithuanian).

5. Mačiulaitis, R. Frost resistance and durability of façade bricks. Frostwiderstand und Dauerhaftigkeit keramischer Fassadenerzeugnisse (Fasadinès keramikos atsparumas šalčiui ir ilgaamžiškumas). Vilnius: Technika, 1996. 132 p. (in Lithuanian, in German).

6. Mačiulaitis, R. Frost resistance and long service life of ceramic facade products. Brick Tile Ind. Int. (Ziegelindustrie International), No 6, 1995, p. 423-440.

7. Sadunas, A.; Bure, D. und Matshjulaitis, R. Novelty in frost resistance of building ceramic bricks (Neue über Frostbeständigkeit der grobkeramischen und Steinerzeugnissen) 12. Ibausil 12. In: International Building Materials and Silicates. Proceedings of conference (Internationale Baustoff und Silikattagung. Tagungsbericht). Part 2. Weimar, 1994, p. 221-231 (in German).

8. Kičaitè, A.; Mačiulaitis, R. Kinetics of ceramic products saturation in aspect of exploitation frost resistance (Keraminiu gaminiu imirkio kinetika eksploatacinio atsparumo šalčiui aspektu). Journal of Civil Engeneering and Management, Vol VIII, Supplement 2. Vilnius: Technika, 2002, p. 126-131 (in Lithuanian).

9. Mačiulaitis, R.; Kičaite, A. Possibilities for Rapid Predicting the Frost Resistance of Facade Ceramics. Materials Science, Vol 8, No 4. Kaunas: Technologija, 2002, p. 469 472.

10. Žurauskienè, R. Sintered building ceramics of easy fusible hidromicous clays with additives. Summary of thesis for Doctor's degree (Sukepusioji statybinè keramika iš hidrožèrutinių lengvai lydžių molių su priedais. Daktaro disertacijos santrauka). Vilnius: Technika, 2002. 32 p. (in Lithuanian).

11. Dondi, M.; Principi, P.; Raimondo, A., Zanarini G. Water vapour permeability of clay bricks. Construction and Building Materials, No 17, 2003, p. 253-258.

12. Glencross-Grant, R.; Walker, P. Survey of buildings sands in Australia. Construction and Building Materials, No 17, 2003, p. 259-268.

13. Nardi, J.V.; Acchar, W.; Hotza, D. Enhancing the properties of ceramic products through mixture design response surface analysis. Journal of the European Ceramic Society, No 24, 2004, p. 375-379.

14. Correia, S.L.; Curto, K. A. S.; Hotza, D.; Segadaes, A. M. Using statistical techniques to model the flexural stregth of dried triaxial ceramic bodies. Journal of the European Ceramic Society, No 25, 2004.

15. Mandeikytè, N.; Šiaučiūnas, R. Laboratory works on ceramics technology (Keraminès technologijos laboratoriniai darbai). Kaunas: Technologija, 1997. 97 p. (in Lithuanian).

16. Balandis, A.; Jasiukevičius, V.; Martynaitis, M.; Strazdas, K. Basics of silicate technology (Silikatu technologijos pagrindai). Vilnius: Mokslo ir enciklopedijų leidykla, 1995. 437 p. (in Lithuanian).

17. Paulaitis, T.; Vyšniauskas, V. Sintered ceramics from local raw materials. In: Proceedings of conference "Building materials, constructions and technologies 95" (Statybinès medžiagos, konstrukcijos ir technologijos 95, konferencijos pranešimų medžiaga). Vilnius: Technika, 1995, p. 33-34 (in Lithuanian).

18. Rudskienè, V.; Kulvietienè, R. Computer data analysis (Kompiuterinė duomenų analizè). Vilnius: Technika, 1995. 47 p. (in Lithuanian).

19. Sakalauskas, V. Statistics with statistics (Statistika su statistika). Vilnius: Margi raštai, 1998. 227 p. (in Lithuanian).

20. Antanavičius, K. Methods of correlation and regression analysis (Koreliacinès ir regresinès analizès metodai). Vilnius: Mintis, 1970. 77 p. (in Lithuanian).

21. Čekanavičius, V.; Murauskas, G. Statistics and its application (Statistika ir jos taikymai). Vilnius, 2000. 238 p. (in Lithuanian).

22. Kaminskas, A.; Smolianskienè, G.; Valiukevičius, Č. Influence of sulphureous fuel oil and additives enhancing sintering to quality of carbonaceous clay ceramic body (Sukepimą skatinančiu priedu ir sieringo mazuto itaka karbonatingo molio keraminès šukès kokybei). Civil Engineering (Statyba), Vol V, No 5, 1999, p. 323-328 (in Lithuanian). 